\title{
Sonication of olive pomace to improve xylanases production by SSF
}

\author{
P. Leite, J.M. Salgado, L. Abrunhosa, A. Venâncio \& I. Belo \\ Center of Biological Engineering, University of Minho, Braga, Portugal
}

\begin{abstract}
Olive mill wastes are an important environmental problem in the areas where they are generated. Portugal is an important producer of olive oil in the world, thus it is interesting to find the most suitable valorization strategy to exploit their wastes which are generated in huge quantities in short periods of time. In this study, it was used the olive pomace as solid substrate to produce xylanases and cellulases by filamentous fungi. To improve the enzymes production ultrasounds pretreatment of olive pomace was evaluated. The results showed that the sonication led to a 3-fold increase of xylanase activity and a decrease of cellulase activity, indicating that ultrasounds treatment attacked the integrity of cell walls and increased the accessibility of hemicelluloses inducing the xylanases production by fungi.
\end{abstract}

\section{INTRODUCTION}

Olive oil is an important component of the Mediterranean diet and its extraction is one of the dominant economic activities in the southern regions Europe. There are three processes of extracting oil, traditional pressed, three-phase system and two-phase system. The two-phase system, a recent process, allows the production of olive oil with economic and environmental benefits because it dramatically reduces the water consumption during the process and the generation of wastewater. This system produces a semi-solid waste, termed two-phase olive mill waste (TPOMW) or olive pomace (OP). In Portugal, about 0.5 million of tons of OP was produced in 2013 from the two-phase olive mills (INE, 2013). As a result of the processes of extraction, the oil industry generates large amounts of waste in a short period of time, and these become an increasing problem of environmental pollution.

Different studies have demonstrated that olive industry by-products are harmful to the environment and that cause negative effects on soil microbial populations (Paredes et al., 1987), on aquatic ecosystems (Dellagreca et al.,2001) and even in air through phenol and sulfur dioxide emissions (Rana et al., 2007). The toxicity and antimicrobial activity of the olive phenols are major contributors to this pollution and hinder the biological treatment of wastes, needed to reduce their pollutant load. Therefore there is an urgent need to find ways of treating these liquid and solid residues from the olive oil industry (Demerche et al., 2013). The biological treatment by fungi can be an efficient use of these wastes to obtain enzymes with industrial interest as cellulases and xylanases.

Cellulases and xylanases are enzymes used to degrade lignocellulosic materials hydrolyzing cellulose and hemicellulose. Their main application is in the saccharification of lignocellulosic materials to obtain fermentable sugars to produce bioethanol. In addition, they have a wide range of applications, including detergents and textile industry, pulp and paper industry, animal feeding, extraction of fruit and vegetable juices, and starch processing (Dogaris et al., 2009). The solid-state fermentation is a technology that allows to produce these enzymes in low cost conditions, mainly due to the use of cheaper substrate such as olive pomace. Numerous fungi 
have been identified as hydrolyzers of cellulose and hemicellulose, however the filamentous fungi considered as strong cellulases and xylanases secreting strains, perform better using SSF (Ang et al., 2013). On an industrial scale, cellulases and xylanases are secreted mainly by Aspergillus and Trichoderma spp. (Kulkarni et al., 1999).

The physical pre-treatments can increase size of pores and accessible surface area, and decrease degrees of polymerization of cellulose and crystallinity, which can be used to improve the biodegradability or enzymatic hydrolysis of these residues (Taherzadeh et al., 2008). Ultrasound pre-treatment causes a cavitation bubbles formation in the liquid phase (Tiehm et al., 2001), the bubbles grow and then violently collapse when they reach a critical size. Cavitational collapse produces turbulence, intense local heating and high pressure at the liquid-gas interface, high shearing phenomena in the liquid phase and formation of radicals (Atchley et al., 1988; Gonze et al., 1998). It was also proven that the degradation of excess sludge is more efficient when using low frequencies: mechanical effects facilitate particles solubilization (Tiehm et al., 2001).

The aim of the present work was to prepare olive pomace for solid-state fermentation by A. niger using ultrasounds pretreatment to improve the accessibility of fungi to hemicellulose and cellulose. Thus, the ultrasounds pretreatment was optimized by full factorial experimental design $\left(3^{2}\right)$ to maximize the production of xylanases and cellulases varying the time of ultrasounds treatment and the liquid and solid ratio.

\section{MATERIALS AND METHODS}

\subsection{Microorganisms}

The fungus used in this study was selected after previously screening, the fungus with higher capacity to degrade the lignocellulosic materials was Aspergillus niger CECT 2915 from the Spanish Type Culture Collection. The fungi was grown on MEA slants at $25{ }^{\circ} \mathrm{C}$ for several days and stored at $4{ }^{\circ} \mathrm{C}$ until used.

\subsection{Characterization of solid substrate}

Two types of olive wastes (crude olive pomace and exhausted olive pomace) were provide by a Portuguese olive oil industrial plant. After olive oil extraction, crude olive pomace (COP) was recovered and stored at $-20^{\circ} \mathrm{C}$. The exhausted olive pomace (EOP) was obtained after recovery residual olive oil and dried, then it was stored at room temperature in dry conditions.

Both wastes were analysed in terms of physical and chemical characteristics, including cellulose, hemicellulose and lignin by quantitative acid hydrolysis (Salgado et al., 2014) . The moisture content and total solids content of wastes was obtained by drying in an oven at $105^{\circ} \mathrm{C}$ during $24 \mathrm{~h}$ to a constant weight. Solid wastes were ovendried to constant weight at $550{ }^{\circ} \mathrm{C}$ to analyse the ashes content. Total nitrogen and organic carbon were determined by a Thermo Finningan Flash Elemental Analyzer 1112 series, San Jose,CA(USA) meanwhile Ca, Mg, Zn, Cu, $\mathrm{Fe}, \mathrm{Mn}, \mathrm{Cr}, \mathrm{Ni}, \mathrm{Pb}, \mathrm{Na}, \mathrm{K}$ were analyzed in ashes using Flame Atomic Absorption and Atomic Emission Spectrometry (FFAS/FAES) FAAS/FAES (Rodríguez-Solana et al., 2013). Reduction sugars, total phenols and protein was analysed in the liquid obtained after extraction process with water (ratio solid:liquid, 1:5 w/v). Reduction sugars was analysed by dinitrosalicylic acid method, protein was determined by Bradford method, total phenols were determined by the Folin-Ciocalteau method using caffeic acid as a standard. Lipids were extracted with diethyl eter and extracts were extracted with ethanol in a Soxtec System HT2 1045 extraction unit.

\subsection{Solid state fermentation}

SSF were carried out in Erlenmeyer flasks with $10 \mathrm{~g}$ of dried solid substrate, moisture was adjusted with water and nutrient solution $\left(5 \mathrm{~g} / \mathrm{L}\right.$ Peptone, $5 \mathrm{~g} / \mathrm{L}$ yeast extract and $\left.0.2 \mathrm{~g} / \mathrm{L} \mathrm{KH}_{2} \mathrm{PO}_{4}\right)$. The solid substrates were COP and EOP for previous fermentation, then EOP was used in fermentions for the optimization of ultrasound treatments. In all experiments, the initial moisture, temperature and inoculated spores were $75 \%$ (wet basis), $30^{\circ} \mathrm{C}$ and $10^{7}$ spores $/ \mathrm{mL}$, respectively. Erlenmeyers flasks with substrates were sterilized at $121{ }^{\circ} \mathrm{C}$ and $15 \mathrm{~min}$, cooled and inoculated 
with $1 \mathrm{~mL}$ of spore solution. The experiments were incubated 6 days, and then enzymes were extracted. All experiments were carried out in duplicate and a control without inoculum was also performed. Enzyme were extracted at fermentation end (6 days) as described by Salgado et al. (2014).

\subsection{Ultrasounds treatment}

The sonication of EOP was carried out with an high intensity ultrasonic processor Cole-Parmer 750 model (Illinois, USA) operating at $750 \mathrm{~W}$ and $20 \mathrm{kHz}$. The solid waste was added to vessel and mixed with water. Different solid and liquid ratios and time of treatment were studied in an experimental design. The vessel was placed in a protective box and the tip (diameter 1/2 ") allocated into the vessel. After treatment, the solid was recovered by vacuum filtration and used as solid substrate in SSF.

\subsection{Experimental design}

For evaluation of sonication effect of EOP in xylanases and cellulases production by SSF a full factorial design $3^{2}$ was carried out. The two studied variables were the time of treatment and the ratio liquid:solid $(\mathrm{v} / \mathrm{w})$, the dependent variables studied were xylanase and cellulase activity. The independent variables considered and their variations ranges are shown in Table 1. The correspondence between coded and uncoded variables was established by linear equations deduced from their respective variation limits. This design allowed the estimation of the significance of the parameters and their interaction using Student's t-test. A second order polynomial model of the form shown in Eq. 1 was used to fit the data:

$$
\mathrm{y}=\mathrm{b}_{0}+\mathrm{b}_{1} \cdot \mathrm{x}_{1}+\mathrm{b}_{11} \cdot \mathrm{x}_{1}{ }^{2}+\mathrm{b}_{2} \cdot \mathrm{x}_{2}+\mathrm{b}_{22} \cdot \mathrm{x}_{2}{ }^{2}+\mathrm{b}_{12} \cdot \mathrm{x}_{1} \cdot \mathrm{x}_{2}+\mathrm{b}_{112} \cdot \mathrm{x}_{1}{ }^{2} \cdot \mathrm{x}_{2}+\mathrm{b}_{122} \cdot \mathrm{x}_{1} \cdot \mathrm{x}_{2}{ }^{2}+\mathrm{b}_{1122} \cdot \mathrm{x}_{1}{ }^{2} \cdot \mathrm{x}_{2}{ }^{2}
$$

where $y$ represents the dependent variable, $\mathrm{b}$ denotes the regression coefficients (calculated from experimental data by multiple regression using the least-squares method), and $\mathrm{x}$ denotes the independent variables. All experiments were carried out in triplicate and in randomized run order.

The experimental data were evaluated by response surface methodology using Statistica 5.0 software. Dependent variables were optimized using an application of commercial software (Solver,Microsoft Excel 2007, Redmon,WA, USA).

Table 1. Levels of independent variables and dimensionless coded variables definition $\left(\mathrm{x}_{\mathrm{i}}\right)$ i.

\begin{tabular}{lccccc}
\hline & & \multicolumn{4}{c}{ Levels } \\
\cline { 2 - 5 } Independent variables & Units & -1 & 0 & 1 & $X_{\mathrm{i}}$ \\
\hline Time $\left(\mathrm{X}_{1}\right)$ & $\mathrm{min}$ & 5 & 10 & 15 & $\left(\mathrm{X}_{1}-10 / 5\right)$ \\
Ratio $\mathrm{L} / \mathrm{S}\left(\mathrm{X}_{2}\right)$ & $\mathrm{g} / \mathrm{g}$ & 3 & 7 & 11 & $\left(\mathrm{X}_{2}-7 / 4\right)$ \\
\hline Dependent variables & Units & & & & \\
\hline Xylanase activity & $\mathrm{U} / \mathrm{g}$ solid substrate & & & \\
Cellulase activity & $\mathrm{U} / \mathrm{g}$ solid substrate & & & \\
\hline
\end{tabular}

\subsection{Enzymatic assays}

Cellulase (endo-1,4- $\beta$-glucanase) activity was analysed using an enzymatic kit Azo-CMCellulase S-ACMC 04/07 (Megazyme International, Ireland). One unit of enzyme activity was defined as the amount of enzyme required to release $1 \mu \mathrm{mol}$ of glucose reducing sugars equivalents from CM-cellulose in $1 \mathrm{~min}$ and $\mathrm{pH} 4.5$.

Xylanase (endo-1,4- $\beta$-xylanase) activity was analysed using an enzymatic kit Azo wheat arabinoxylan AWX 10/2002 (Megazyme International, Ireland). One unit of enzyme activity was defined as the amount of enzyme required to release $1 \mu \mathrm{mol}$ of xylose reducing sugar equivalents from wheat arabinoxylan in $1 \mathrm{~min}$ and $\mathrm{pH} 4.5$. 


\section{RESULTS}

\subsection{Characterization of EOP and COP}

The solids wastes from olive mill wastes were characterized to evaluate their potential as solid substrate in SSF. The crude olive pomace (COP) was directly collected after olive oil extraction obtaining a wet solid waste, however the exhausted olive pomace (EOP) was recovered after extraction of residual olive oil and dried, these processes were carried out to use the solid waste in combustion processes. As can be observed in Table 2 the moisture content and total solids were very different due to the dried processes. The free reduction sugars, protein were higher in COP, these compounds could have been extracted in the recovered of residual olive oil. This effect is clear in reduction of lipids content which were reduced from $16.65 \%$ to $3.93 \%$.

Table 2. Characterization of olive mill wastes

\begin{tabular}{lcc}
\hline Parameter & Crude olive pomace & Exhausted olive pomace \\
\hline Humidity (\% fresh weight) & $73.5 \pm 0.4$ & $9.86 \pm 0.12$ \\
Total solids (\%) & $26.5 \pm 0.4$ & $90.12 \pm 0.12$ \\
Extracts (\%) & $2 \pm 0.7$ & $4.19 \pm 0.86$ \\
Lignin (\%) & $34.6 \pm 1.1$ & $37.16 \pm 0.32$ \\
Hemicellulose (\%) & $39.1 \pm 4.5$ & $36.98 \pm 4,07$ \\
Cellulose (\%) & $33.5 \pm 1.1$ & $30.03 \pm 3,28$ \\
Lipids (\%) & $16.6 \pm 0.1$ & $3.93 \pm 1.94$ \\
Reducing sugars (mg/g) & $97.5 \pm 7.1$ & $41.49 \pm 2.12$ \\
Proteins (mg/g) & $3.6 \pm 1.4$ & $2.55 \pm 0.26$ \\
Phenols (mg/g) & $8.3 \pm 0.3$ & $8.77 \pm 0.23$ \\
$\mathrm{Ash}(\%)$ & $6.6 \pm 0.5$ & $3.36 \pm 0.18$ \\
$\mathrm{~N}(\%)$ & $0.60 \pm 0.10$ & $1.27 \pm 0.07$ \\
$\mathrm{C}(\%)$ & $49.72 \pm 0.68$ & $46.07 \pm 1.29$ \\
$\mathrm{Ca}(\mathrm{g} / \mathrm{kg})$ & $1.16 \pm 0.04$ & $1.75 \pm 0.18$ \\
$\mathrm{~K}(\mathrm{~g} / \mathrm{kg})$ & $16.86 \pm 1.00$ & $14.17 \pm 0.72$ \\
$\mathrm{Mg}(\mathrm{mg} / \mathrm{kg})$ & $473.50 \pm 21.92$ & $473.00 \pm 56.57$ \\
$\mathrm{Zn}(\mathrm{mg} / \mathrm{kg})$ & $12.00 \pm 0.00$ & $10.50 \pm 0.71$ \\
$\mathrm{Cu}(\mathrm{mg} / \mathrm{kg})$ & $11.50 \pm 0.71$ & $11.00 \pm 1.41$ \\
$\mathrm{Fe}(\mathrm{mg} / \mathrm{kg})$ & $41.50 \pm 2.12$ & $146.50 \pm 33.23$ \\
$\mathrm{Mn}(\mathrm{mg} / \mathrm{kg})$ & $8.60 \pm 0.14$ & $10.20 \pm 0.42$ \\
$\mathrm{Cr}(\mathrm{mg} / \mathrm{kg})$ & $<22$ & $<22$ \\
$\mathrm{Ni}(\mathrm{mg} / \mathrm{kg})$ & $<22$ & $<22$ \\
$\mathrm{~Pb}(\mathrm{mg} / \mathrm{kg})$ & $<22$ & $<22$ \\
$\mathrm{Na}(\mathrm{mg} / \mathrm{kg})$ & $373.00 \pm 35.36$ & $91.50 \pm 4.95$ \\
\hline
\end{tabular}

The content in cellulose, hemicellulose and lignin were similar in both residues and other residues studied in literature (Roig et al., 2006), the higher content of hemicelluloses and lignin indicated that these wastes have potential to be used as solid substrate in solid-state fermentation.

The analysis of $\mathrm{C}$ and $\mathrm{N}$ showed an increase of $\mathrm{N}$ content and decrease of $\mathrm{C}$ after extraction of residual oil, in the mineral content the values was not different, except to the Fe content that was higher in EOP and the content of $\mathrm{Na}$ that was higher in COP.

\subsection{Solid-state fermentation of EOP and COP}

The solid wastes EOP and COP were evaluated as solid substrate for cellulases and xylanases production in SSF by A. niger. Table 3 shows the cellulase and xylanase activities achieved. $A$. 
niger showed higher cellulase and xylanase activity using exhausted olive pomade. This solid was selected to evaluate the effect of ultrasounds treatment on cellulase and xylanase production by $A$. niger in SSF.

Table 3. Enzymatic activity of extracts from solid-state fermentation of olive mill wastes

\begin{tabular}{lccccc}
\hline & \multicolumn{2}{c}{ CELLULASES } & & \multicolumn{2}{c}{ XYLANASES } \\
\cline { 2 - 3 } \cline { 5 - 6 } \cline { 5 - 6 } & COP & EOP & & COP & EOP \\
\hline A. uvarum & $0.47 \pm 0.03$ & $16.70 \pm 0.97$ & & $0.13 \pm 0.06$ & $7.80 \pm 0.37$ \\
A. ibericus & $2.12 \pm 0.66$ & $18.87 \pm 4.74$ & & $0.42 \pm 0.19$ & $7.22 \pm 1.35$ \\
A. niger & $1.22 \pm 0.26$ & $47.55 \pm 1.79$ & & $0.81 \pm 0.53$ & $25.89 \pm 2.72$ \\
\hline
\end{tabular}

\subsection{Effect of ultrasounds pretreatment on enzymes production by SSF}

EOP was selected to study the effect of its sonication. Thus, two variables of ultrasound treatment were evaluated in a full factorial design $3^{2}$. $r$. Table 4 depicts the corresponding experimental matrix and the results obtained. The two responses studied were cellulase and xylanase activity. As can be observed, the ultrasounds treatment had a positive effect in xylanase production, however the cellulase activity decreased after ultrasound treatment. The positive effect of ultrasounds pretreatment on xylanase production by SSF of rice hull was also observed by Yang et al. (2011).

Table 4. Design matrix and response values.

\begin{tabular}{ccccc}
\hline Run & $\begin{array}{c}\text { Time } \\
(\mathrm{min})\end{array}$ & $\begin{array}{c}\text { Ratio L/S } \\
(\mathrm{mL} / \mathrm{g})\end{array}$ & $\begin{array}{c}\text { Cellulases } \\
(\mathrm{U} / \mathrm{g})\end{array}$ & $\begin{array}{c}\text { Xylanases } \\
(\mathrm{U} / \mathrm{g})\end{array}$ \\
\hline 1 & 5 & 3 & 28.94 & 27.351 \\
2 & 5 & 7 & 18.31 & 28.839 \\
3 & 5 & 11 & 37.28 & 7.533 \\
4 & 10 & 3 & 16.59 & 11.463 \\
5 & 10 & 7 & 7.49 & 69.107 \\
6 & 10 & 11 & 8.40 & 26.881 \\
7 & 15 & 3 & 20.96 & 55.518 \\
8 & 15 & 7 & 18.13 & 69.863 \\
9 & 15 & 11 & 17.30 & 48.639 \\
10 & 10 & 7 & 8.58 & 70.862 \\
11 & 10 & 7 & 7.91 & 70.166 \\
\hline
\end{tabular}

The optimal conditions that led to maximum xylanase activity $(75.32 \mathrm{U} / \mathrm{g})$ were calculated with Solver tool showing $12.41 \mathrm{~min}$ and 7.27 of liquid and solid ratio as optimal parameters of ultrasound treatment. Figure 1 displays the estimated response surface obtained from the data analysis of the matrix.

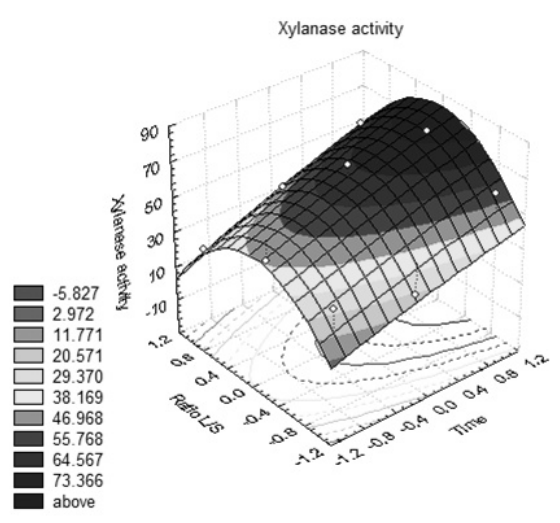


Figure 1. Estimated response surface from the full factorial design $3^{2}$.

An optimal clear zone can be seen at intermediate liquid and solid ratios and maximum time studied. The validation of the model was performed in the optimal conditions, the xylanase activity achieved was close to the maximum value predicted by the model.

\section{CONCLUSIONS}

Olive mill wastes showed to be a suitable solid substrate for cellulase and xylanase production. The maximum cellulase and xylanase activities were achieved using exhausted olive pomace as solid substrate.

The ultrasounds treatment of exhausted olive pomace improved xylanase production by SSF using A. niger. The optimal conditions of treatment were $12.41 \mathrm{~min}$ and a liquid and solid ratio of 7.27. Ultrasounds treatment showed a negative effect on cellulase production. Thus the sonication can be an effective treatment to induce the production of xylanases by SSF. In future works, it will be studied other treatments in combination with sonication to improve cellulase production.

\section{REFERENCES}

Ang, S.K., Shaza, E.M., Adibah, Y., Suraini, A.A., Madiha, M.S. 2013. Production of cellulases and xylanase by Aspergillus fumigatus SK1 using untreated oil palm trunk through solid state fermentation. Process Biochemistry, 48(9):1293-1302.

Atchley, A.A. \& Crum, L.A. 1988. Acoustic cavitation and bubble dynamics. In K.S. Suslick (eds), Ultrasound - its chemical, physical, and biological effects: 1-64, VCH Publishers, New York.

DellaGreca, M., Monaco, P., Pinto, G., Pollio, A., Previtera, L. \& Temussi, F. 2001. Phytotoxicity of Low-Molecular-Weight Phenols from Olive Mill Waste Waters. Bulletin of environmental contamination and toxicology, 67:352-359.

Dermeche, S., Nadour, M., Larroche, C., Moulti-Mati, F. \& Michaud, P. Olive mill wastes: Biochemical characterizations and valorization strategies. Process Biochem. 48, 1532-1552 (2013).

Dogaris, I., Vakontios, G., Kalogeris, E., Mamma, D. \& Kekos, D. 2009. Induction of cellulases and hemicellulases from Neurospora crassa under solid-state cultivation for bioconversion of sorghum bagasse into ethanol, 9:404-411.

Gonze, E., Gonthier, Y., Boldo, P. \& Bernis, A. 1998. Standing waves in a high frequency sonoreactor: Visualization and effects. Chemical Engineering Science 53:523-532.

Kulkarni, N., Shendye, A. \& Rao, M., 1999. Molecular and biotechnological aspects of xylanases. FEMS Microbiology Reviews, 23:411-456.

Paredes, M.J., Moreno, E., Ramos-Cormenzana, A. \& Martinez, J. 1987. Characteristics of soil after pollution with waste waters from olive oil extraction plants. Chemosphere 16:1557-1564.

Rana, G., Rinaldi, M. \& Introna, M. 2003. Volatilisation of substances after spreading olive oil waste water on the soil in a Mediterranean environment. Agriculture, Ecosystems and Environment, 96:49-58.

Roig, A., Cayuela, M. L., \& Sánchez-Monedero, M. A. 2006. An overview on olive mill wastes and their valorisation methods. Waste Management, 26:960-969.

Salgado, J.M., Abrunhosa, L., Venâncio, A., Domínguez, J.M. \& Belo, I. 2013. Screening of winery and olive mill wastes for lignocellulolytic enzyme production from Aspergillus species by solid-state fermentation. Biomass Conversion and Biorefinery, 4:201-209.

Taherzadeh, M.J. \& Karimi, K. 2008. Pretreatment of lignocellulosic wastes to improve ethanol and biogas production: a review. International Journal of Molecular Science, 9:1621-51.

Tiehm, A., Nickel, K., Zellhorn, M. \& Neis, U. 2001. Ultrasonic waste activated sludge disintegration for improving anaerobic stabilization. Water Research, 35:2003-2009.

Yang, C., Sheih, I., \& Fang, T. J. 2012. Fermentation of rice hull by aspergillus japonicus under ultrasonic pretreatment. Ultrasonics Sonochemistry, 19:687-691. 